\title{
PENYUSUNAN RENSTRA DESA WISATA BUNGA PADA KAWASAN EKOWISATA SEBAGAI UPAYA PENINGKATAN KESEJAHTERAAN MASYARAKAT DESA JETIS KECAMATAN BANDUNGAN KABUPATEN SEMARANG
}

\author{
Miftah Arifin ${ }^{1}$, Yanto $^{2}$ \\ Fakultas Ekonomi dan Bisnis, Universitas Islam Nahdlatul Ulama Jepara \\ email: miftah012001@gmail.com¹ yanto@unisnu.ac.id ${ }^{2}$
}

Key word:

Strategic Plan for

the Village,

"Tourism Village of

Flowers",

Ecotourism, Welfare

Kata Kunci

Renstrades, Desa

Wisata Bunga,

Ekowisata,

Kesejahteraan

\begin{abstract}
Regional policies on the development of Jetis as "tourism village flower", must continue to be developed because it can provide reciprocal benefits for humans and the environment. Unfortunately, the management concept of "tourist village built environment interest" in ecotourism in Jetis, not to apply the principle of participation-partnership between government and society, as well as the concept of the relationship between society and the environment. This activity uses the dissemination and facilitation techniques, so that the public is able to apply management "Tourism Village of Flowers" independently, through the Strategic Plan. As a result, synergy partnerships between government and community is key to accelerating the success of ecotourism programs of interest for the welfare of society.
\end{abstract}

\begin{abstract}
Abstrak
Kebijakan pengembangan Desa Jetis sebagai kawasan lingkungan desa wisata bunga, harus terus dikembangkan karena dapat memberikan manfaat timbal balik bagi manusia dan lingkungan. Sayangnya, konsep pengelolaan lingkungan binaan desa wisata bunga pada kawasan ekowisata di Desa Jetis, belum menerapkan prinsip partisipasi-kemitraan antara pemerintah dan masyarakat, maupun konsep hubungan antara masyarakat Desa Jetis dengan lingkungannya. Diseminasi ini menggunakan teknik ceramah, diskusi, penayangan film dan pendampingan agar masyarakat mampu secara mandiri menerapkan tata kelola Desa Wisata Bunga, melalui penyusunan Renstra Desa. Hasilnya, sinergitas kemitraan antara pemerintah dan masyarakat adalah kunci untuk mempercepat keberhasilan program ekowisata bunga demi kesejahteraan masyarakat.
\end{abstract}




\section{PENDAHULUAN}

Pembentukan dan pengelolaan kawasan binaan desa wisata bunga di daerah wisata Desa Jetis, adalah merupakan contoh model konsep yang baik dalam pengelolaan lingkungan yang dilakukan secara komprehensif dan terintegratif, serta dalam membangun hubungan yang harmonis antara manusia dan lingkungannya. Sebab, manusia seperti halnya semua makhluk hidup, berinteraksi dengan lingkungan hidupnya (Sukmana, 2003: 38). Interaksi antara individu dan lingkungannya tersebut dapat dikategorikan ke dalam 4 jenis, yaitu: (i) bertentangan dengan lingkungan; (ii) menggunakan lingkungan; (iii) berpartisipasi (ikut serta) dengan lingkungan; dan (iv) menyesuaikan diri dengan lingkungan.

Menurut Walgito (1994: 20-26), hubungan antara individu dengan lingkungannya, terutama lingkungan sosial tidak hanya berlangsung searah, akan tetapi terdapat hubungan timbal balik dan saling mempengaruhi. Oleh karena itu, pengelolaan lingkungan hidup merupakan upaya terpadu untuk melestarikan fungsi lingkungan hidup yang meliputi kebijaksanaan dalam hal penataan, pemanfaatan, pengembangan, pemeliharaan, pemulihan, pengawa-san, dan pengendalian lingkungan hidup.

Menurut UU No. 23 Tahun 1997 tentang Pengelolaan Lingkungan Hidup, yang dimaksud dengan lingkungan hidup adalah kesatuan ruang dengan semua benda, daya, keadaan, dan makhluk hidup, termasuk manusia dan perilakunya, yang mempengaruhi kelangsungan perikehidupan dan kesejahteraan manusia serta makhluk hidup lainnya. Sejalan dengan konsep tersebut, Soekanto (1986: 19) menyatakan apabila seseorang membicarakan lingkungan hidup, maka biasanya yang dipikirkan adalah hal-hal atau apa-apa yang berada di sekitar manusia, baik sebagai individu maupun dalam pergaulan hidup.

Bahkan Purba (2002: 39) menyatakan bahwa manusia memerlukan lingkungan sosial yang serasi demi kelangsungan hidupnya. Lingkungan sosial yang serasi itu bukan hanya dibutuhkan oleh seorang saja, tetapi juga oleh seluruh orang di dalam kelompoknya. Untuk mewujudkan lingkungan sosial yang serasi itu diperlukan lagi kerjasama kolektif di antara sesama anggota. Kerjasama itu dimaksudkan untuk membuat dan melaksanakan aturan-aturan yang disepakati bersama oleh warga sebagai mekanisme pengendalian perilaku sosial. 
Aturan-aturan itu, seringkali terwujud dalam bentuk pranata atau norma-norma sosial yang harus dipatuhi oleh setiap anggota kelompok (norma hukum).

Bandungan, adalah merupakan salah satu kawasan wisata utama di Kabupaten Semarang, terutama jenis ekowisata. Dalam pengembangan daerah wisata Desa Jetis, pemerintah daerah membentuk lingkungan binaan, yaitu Desa Jetis yang dikelola sebagai desa wisata bunga. Lingkungan desa wisata tersebut dikelola secara baik dan terencana sehingga memiliki karakteristik yang unik sebagai suatu lingkungan binaan, yang memberikan nilai manfaat bagi masyarakat setempat.

Pengelolaan lingkungan binaan desa wisata adat dan wisata bunga pada Kawasan Daerah Ekowisata Desa Jetis, Kabupaten Semarang, adalah merupakan suatu model konsep pengelolaan lingkungan yang baik, yang dapat memberikan dampak positif timbal-balik bagi masyarakat dan lingkungan setempat. Pertanyaan dasar yang muncul adalah bagaimana konsep dan proses pengelolaan lingkungan binaan tersebut dilakukan? Bagaimana manfaat positifnya baik bagi masyarakat maupun lingkungan? dan sebagainya.
Permasalahan yang teridentifikasi, antara lain:

1. Rendahnya pemahaman masyarakat tentang pengembangan dan pengelolaan kawasan lingkungan desa wisata bunga.

2. Lemahnya sikap partisipatif masyarakat dalam pengembangan dan pengelolaan kawasan lingkungan desa wisata bunga.

3. Belum sistematisnya disain dan rekayasa lingkungan (pembentukan lingkungan) desa wisata bunga.

4. Belum terpenuhinya dokumen renstra desa mengenai konsep kebijakan pemerintah dalam pengembangan kawasan lingkungan binaan desa wisata bunga pada Kawasan Daerah Ekowisata Desa Jetis Bandungan.

Pembinaan hukum dan pengelolaan lingkungan binaan desa wisata bunga pada Kawasan Daerah Ekowisata Desa Jetis, Kabupaten Semarang merupakan suatu tuntutan keharusan bagi tercapainya peningkatan kesadaran lingkungan masyarakat di Desa Jetis dan sinergitas kemitraan antara pemerintah dan masyarakat untuk mempercepat keberhasilan program ekowisata bunga di Desa Jetis Bandungan Kabupaten Semarang. Pengabdian ini dilakukan untuk melakukan diseminasi dan pendampingan mengenai mengapa dan bagaimana model dan konsep pengelolaan lingkungan binaan 
desa wisata bunga pada Kawasan Daerah Ekowisata Desa Jetis, Kabupaten Semarang. Dari hasil pengabdian ini diharapkan akan diperoleh informasi dan dasar-dasar strategi tentang penerapan konsep pengelolaan lingkungan yang baik, untuk dapat dikembangkan di kawasan ekowisata di daerah lainnya. Secara khusus, kegiatan ini ini bertujuan untuk:

1. Meningkatkan pemahaman masyarakat tentang pengembangan dan pengelolaan kawasan lingkungan desa wisata bunga.

2. Memperkuat sikap partisipatif masyarakat dalam pengembangan dan pengelolaan kawasan lingkungan desa wisata bunga.

3. Mendampingi penerapan secara sistematis disain dan rekayasa lingkungan (pembentukan lingkungan) desa wisata bunga.

4. Melakukan pendampingan penyusunan Renstradesa wisata bunga pada Kawasan Daerah Ekowisata Desa Jetis Bandungan.

Sedangkan luaran atau manfaat dari kegiatan ini bagi khalayak sasaran strategis adalah terciptanya pemahaman komprehensif (hukum, sosial, lingkungan), untuk meningkatkan pemahaman dan partisipasi masyarakat dalam penyusunan Renstrades mengenai pengembangan dan pengelolaan kawasan lingkungan desa wisata bunga melalui penerapan secara sistematis disain dan rekayasa lingkungan (pembentukan lingkungan) desa wisata bunga. Adapun bagi pemerintah daerah maupun pemerintah desa dapat terbantu untuk menginformasikan dan menyebarluaskan dengan baik konsep kebijakan pemerintah dalam pengembangan kawasan lingkungan binaan desa wisata bunga pada Kawasan Daerah Ekowisata Desa Jetis Bandungan. Harapannya, tercapai peningkatan partisipasi masyarakat dalam pengembangan dan pengelolaan kawasan lingkungan desa wisata bunga melalui penyusunan renstra desa wisata bunga.

\section{METODOLOGI PELAKSANAAN}

Metode yang digunakan pada pelaksanaan kegiatan ini adalah metode diseminasi (ceramah, diskusi, dan penayangan film), untuk meningkatkan pemahaman dan partisipasi masyarakat tentang pengembangan dan pengelolaan kawasan lingkungan desa wisata bunga serta untuk menginformasikan dan menyebarluaskan dengan baik konsep kebijakan pemerintah dalam pengembangan kawasan lingkungan binaan desa wisata bunga pada Kawasan Daerah Ekowisata Desa Jetis Bandungan. Selain itu juga menggunakan metode 
pendampingan, untuk memastikan penerapan secara sistematis disain dan rekayasa lingkungan desa wisata bunga.

Khalayak sasaran dalam kegiatan pengabdian ini adalah komunitas lingkungan binaan di Desa Jetis sebagai desa wisata bunga, pada kawasan ekowisata Bandungan. Sasaran strategisnya adalah para pemimpin \& tokoh masyarakat serta warga masyarakat, khususnya Paguyuban Pedagang Tanaman Hias Jetis (PPTHJ) dan Paguyuban Petani Bunga Bandungan (PP2B). Diseminasi ini telah diselenggarakan pada, Sabtu tanggal 20 Agustus 2016, bertempat di Balai Desa Jetis, Kecamatan Bandungan Kabupaten Semarang, diikuti oleh 25 orang peserta aktif. Adapun pendampingan dilakukan dalam pleno penetapan Renstra Desa Wisata bunga pada hari Jumat, tanggal 21 Oktober 2016.

\section{HASIL DAN PEMBAHASAN}

Kegiatan pengabdian ini akan dilakukan dalam 3 (tiga) tahapan, yaitu: (1) tahap persiapan dengan membuat rancangan kegiatan berdasarkan analisis kebutuhan, melalui observasi dan brainstorming; (2) melakukan kegiatan yang berbentuk diseminasi; (3) melakukan pendampingan.

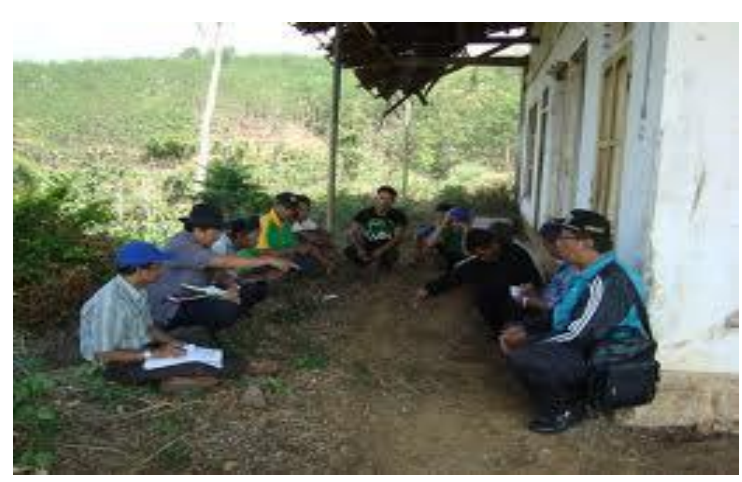

Gambar 1. Brainstorming dengan Petani Bunga

Pada tahap persiapan, Tim Pengabdian mengadakan pertemuan anggota tim yang dilanjutkan dengan pembagian kerja. Anggota Tim yang bertugas mengkoordinasikan kerjasama dan perijinan dengan Kepala Desa Jetis, serta memohon masukan dan saran tentang peserta, tempat, dan waktu pelaksanaan. Anggota yang lain bertugas mempersiapkan segala sesuatu yang berkaitan dengan pelaksanaan kegiatan, seperti LCD, makalah, transportasi, dokumentasi, dsb. Tahap analisis kebutuhan (brainstorming) ini dilakukan pada tanggal 2 Agustus 2016 untuk menganalisis potensi \& daya dukung lingkungan alam, sosial \& budaya kawasan Desa Jetis, dengan hasil identifikasi bahwa:

1. Partisipasi masyarakat sudah cukup tinggi dalam mendukung program pengembangan Desa Jetis sebagai desa wisata bunga melalui pemanfaatan lahan pertanian, halaman rumah dan 
areal lainnya sebagai lahan pertanian tanaman bunga hias.

2. Belum tersistematisnya pola penataan sepanjang jalan Desa Jetis sebagai areal pemasaran bunga.

3. Belum optimalnya pembangunan sarana dan prasarana, seperti akses jalan dan pasar bunga, belum optimal.

4. Belum terrealisasinya pengembangan areal wisata bunga, tempat penginapan, dan fasilitas wisata bunga lainnya.

5. Belum adanya program-program rutin pendukung yang dapat menarik wisatawan untuk datang ke kawasan desa wisata bunga, misalnya diadakan festival bunga, pameran dan lomba bunga, dan sebagainya

Kegiatan diseminasi ini dilaksanakan di ruang pertemuan BPD Desa Jetis Kecamatan Bandungan, pada hari Sabtu, tanggal 20 Agustus 2016 dari Jam 08.00 14.00. Peserta diseminasi yang hadir sebanyak 25 orang peserta dari perangkat desa, paguyuban petani bunga, tokoh masyarakat dan tokoh pemuda. Dengan representasi kehadiran para peserta, menunjukkan keberhasilan kegiatan sesuai dengan perencanaan sebelumnya.

Kegiatan diseminasi ini dihadiri dan dibuka oleh Kepala Desa Jetis, Fajar Budi Laksono, A.Md. Bahkan Kepala Desa dan seluruh Kepala Dusun mengikuti acara hingga selesai. Dalam sambutannya, Kepala Desa menyebutkan bahwa prioritas pembangunan desa akan diarahkan pada program-program peningkatan kesejahteraan masyarakat yang proterhadap lingkungan, diantaranya adalah "Program Desa Wisata Bunga". Kegiatan diseminasi ini merupakan manifestasi konkrit kepedulian kaum intelektual yang berasal dari kampus terhadap pemenuhan informasi dan strategi yang dibutuhkan masyarakat desa.

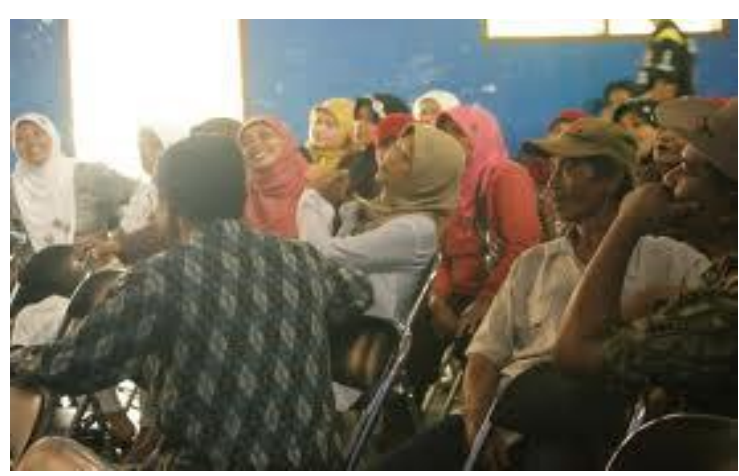

Gambar 2. Diseminasi Renstra

Setelah pembukaan, kegiatan diseminasi dilanjutkan dengan pemberian pre-test kepada peserta sebagai penjajagan seberapa banyak pengetahuan dan pemahaman peserta mengenai program Desa Wisata Bunga dan perihal hukum lingkungan sebelum mengikuti diseminasi ini. Hal ini penting untuk mengetahui efektivitas kegiatan diseminasi yang dilakukan.

Strategi penyampaian materi diseminasi diawali dengan refleksi dan evaluasi terhadap pengetahuan dan sikap 
peserta terkait persoalan sosial, hukum, dan lingkungan, khususnya mengenai "Desa Wisata Bunga", kemudian ditayangkan testimoni keberhasilan "Desa Wisata Bunga" melalui pemutaran film dokumenter. Berikutnya sesi ceramah mengenai "Tata Kelola Lingkungan Berbasis Ekowisata" disampaikan secara singkat dan dilanjutkan diskusi terfokus "Pembinaan Hukum Lingkungan dan Prospektus Desa Wisata Bunga sebagai Upaya Peningkatan Kesejahteraan”.

Setelah seluruh rangkaian ceramah dan diskusi selesai, kemudian post-test dilakukan untuk melihat seberapa banyak pengetahuan mereka bertambah setelah mendengarkan materi diseminasi. Terakhir, peserta mengisi lembar assestmen yang berisi ada tidaknya manfaat diseminasi ini bagi mereka serta masukan yang dapat diberikan untuk kegiatan serupa di lain waktu. Setelah istirahat siang dilanjutkan dengan rencana tindak lanjut (RTL) dengan agenda penyusunan road map percepatan program "Desa Wisata Bunga".

Skor hasil pre-test dan post-test menunjukkan adanya perbedaan pemahaman peserta diseminasi ini sebelum (pre-test) sebesar 4,13 dan sesudah (posttest) diseminasi sebesar 4,94. Hal ini berarti kegiatan diseminasi yang dilakukan cukup efektif dalam memberikan pemahaman kepada peserta mengenai potensi "Desa Wisata Bunga".

Secara umum kegiatan diseminasi ini cukup berhasil dan tepat sasaran, karena para peserta merupakan pemangku kepentingan dalam Program Desa Wisata Bunga. Bahkan di akhir acara mereka menginginkan kegiatan ini berkelanjutan. Jumlah peserta yang tidak berkurang dari pagi sampai selesai juga merupakan indikasi bahwa para peserta serius dalam mengikuti kegiatan diseminasi ini.

Adapun pendampingan dilakukan dalam pleno antara Pemerintah Desa, BPD dan Stakeholders guna penetapan Renstra Desa Wisata Bunga yang dihadiri oleh 25 orang pada tanggal 21 Oktober 2016.

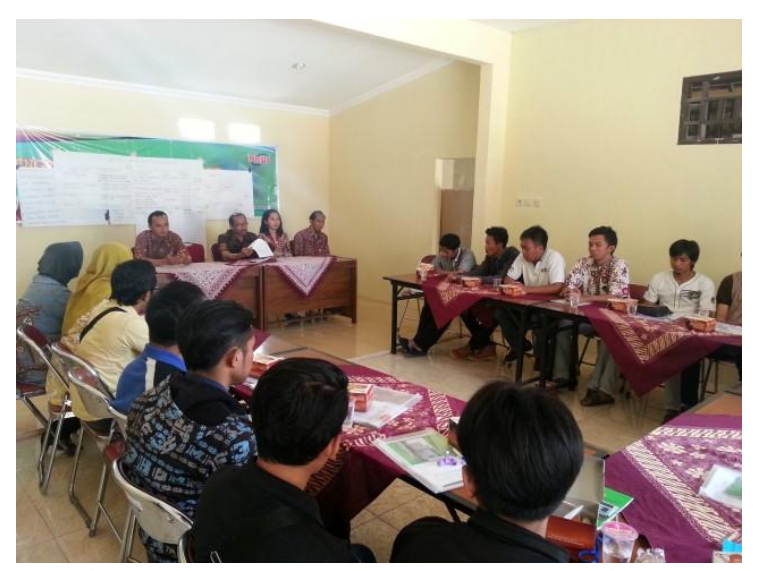

Gambar 3. Pemaparan Program Unggulan

Hasil kegiatan pendampingan yang tertuang dalam Renstra Desa Wisata Bunga menunjukkan bahwa: 
1. Idealnya pengembangan wisata program desa wisata bunga, dibagi menjadi 2 (dua) koridor pengembangan, yaitu:

a. Wilayah Barat, dapat dikembangkan untuk pusat wisata agribisnis, berpusat di Dusun Deso, Ngawinan, dan Krajan.

b. Wilayah Timur, yang dikembangkan untuk pusat wisata home industri bunga, berpusat di Dusun Jetis dan Jombor.

2. Pengembangan kawasan desa wisata bunga, harus diarahkan pada daya tarik wisata yang meliputi:

a. Stand bunga di koridor jalan raya Desa Jetis;

b. Budidaya bunga di kawasan permukiman penduduk;

c. Budidaya bunga potong di Desa Jetis;

d. Agenda rutin festival bunga, dan Rekayasa pengolahan produksi bunga, menjadi produk olahan yang khas.

Perlunya dukungan optimal dari Pemerintah Kabupaten Semarang, baik aspek perencanaan, pendanaan, maupun pengawasan dan pendampingan dalam pengembangan kawasan desa wisata bunga di Desa Jetis.

\section{KESIMPULAN}

Kesimpulan dari kegiatan pengabdian ini yaitu:

1. Keberhasilan kegiatan diseminasi ini ditunjukkan perbedaan skor yang diperoleh dari hasil pre-test terhadap post-test, yaitu 4,13 dengan 4,94.

2. Pada dasarnya masyarakat Desa Jetis sangat setuju dan mendukung terhadap pengembangan kawasan desa wisata bunga, namun demikian masih ada kekhawatiran dari masyarakat terutama berkaitan dengan masuknya pemodal dan menguasai pemasaran bunga.

3. Bentuk partisipasi masyarakat dalam pengembangan dan pengelolaan kawasan lingkungan Desa Jetis sebagai kawasan desa wisata bunga, dideskripsikan sebagai berikut: (a) Partisipasi masyarakat dalam pemanfaatan lahan pertanian, halaman rumah dan areal lainnya sebagai lahan pertanian tanaman bunga hias; (b) Penataan sepanjang jalan Desa Jetis sebagai areal pemasaran bunga; (c) Pembangunan sarana dan prasarana pendukung, seperti akses permodalan melalui BUMDes, ataupun pasar khusus bunga; dan (d) Pengembangan kawasan/ areal wisata bunga, flower views, dan fasilitas wisata bunga lainnya. 
4. Pendampingan penyusunan Renstra Desa Wisata Bunga dilakukan dalam pleno antara Pemerintah Desa, BPD dan Stakeholders yang menghasilkan pokok-pokok perencanaan strategis, yaitu: (a) Pengembangan program desa wisata bunga, dibagi menjadi 2 (dua) koridor pengembangan, yaitu Wilayah Barat sebagai pusat wisata agribisnis (Dusun Deso, Ngawinan, dan Krajan), dan Wilayah Timur sebagai pusat wisata home industri bunga (Dusun Jetis dan Jombor); (b) Pengembangan kawasan desa wisata bunga, harus diarahkan pada daya tarik wisata, meliputi: stand bunga di koridor jalan raya Desa Jetis, budidaya bunga di kawasan permukiman penduduk; budidaya bunga potong di Desa Jetis; Agenda rutin festival bunga dan rekayasa pengolahan produksi bunga, menjadi produk olahan yang khas.

\section{SARAN}

Saran berkait dengan pelaksanaan atau hasil Pengabdian kepada Masyarakat ini, yaitu:

1. Untuk lebih mengoptimalkan percepatan "Program Desa Wisata Bunga", perlu dilakukan kegiatan lanjutan dengan melibatkan instansiinstansi baik di tingkat kecamatan ataupun kabupaten agar terjadi kerjasama lintas sektoral yang saling berkesinambungan.

2. Kebijakan pengembangan lingkungan Desa Jetis sebagai kawasan lingkungan desa wisata bunga, harus terus dikembangkan karena dapat memberikan manfaat timbal balik bagi manusia dan lingkungan.

3. Pemerintah Kabupaten Semarang perlu terus melakukan upaya sosialisasi tentang kebijakan pengembangan kawasan lingkungan Desa Jetis sebagai kawasan lingkungan desa wisata bunga kepada masyarakat, sehingga partisipasi masyarakat dalam mendukung program ini semakin baik.

4. Pemerintah Kabupaten Semarang, khususnya Dinas Pariwisata dan Dinas Perindustrian Dan Perdagangan (UMKM) harus memberikan dukungan optimal baik aspek perencanaan, pendanaan, maupun pengawasan dan pendampingan dalam pengembangan kawasan desa wisata bunga di Desa Jetis.

\section{UCAPAN TERIMAKASIH}

Ucapan terimakasih ini kami sampaikan kepada :

1. Kepala Desa Jetis, yaitu Bapak Fajar Budi Laksono, A.Md. yang telah 
berkenan bekerjasama dalam kegiatan pengabdian ini dan terima kasih atas masukannya terhadap "Program Desa Wisata Bunga" untuk peningkatan kesejahteraan masyarakat.

2. Seluruh Kepala Dusun yang berpartisipasi dalam mengikuti acara diseminasi hingga selesai.

3. Ketua dan anggota BPD Desa Jetis Kecamatan Bandungan yang telah memfasilitasi tempat dan prasarana dan sarana sehingga acara ini berjalan dengan sukses.

4. Peserta diseminasi yang hadir dari perangkat desa, paguyuban petani bunga, tokoh masyarakat dan tokoh pemuda yang setia mengikuti acara sampai selesai.

5. Tidak lupa terima kasih juga kepada Tim Pengabdian "Program Desa Wisata Bunga", terma kasih atas dedikasinya dalam pengabdian ini sehingga "Program Desa Wisata Bunga" berjalan dengan lancar dan selesai dengan baik.

\section{DAFTAR PUSTAKA}

Purba, Jonny. 2002. Pengelolaan Lingkungan Sosial. Jakarta: Yayasan Obor Indonesia.

Sarwono, Sarlito, W. 1995. Psikologi Lingkungan. Jakarta: Gramedia.
Sukmana, Oman. 2005. "Pengaruh Kepadatan Sosial dan Persepsi tentang Lingkungan Sosial daerah Kumuh Perkotaan terhadap Perilaku Agresif Remaja”. Jurnal Psikodinamik, Volume 7, No. 1 Januari 2005, ISSN 1411-3929. Malang: Fakultas Psikologi UMM.

Sukmana, Oman. 2003. Dasar-Dasar Psikologi Lingkungan. Malang: Bayu Media.

Soekanto, Soerjono. 1986. Sosiologi: Suatu Pengantar. Jakarta: Rajawali Press.

Soemarwoto, Otto. 1997. Analisis Mengenai Dampak Lingkungan. Yogyakarta: Gadjah Mada University Press.

Walgito, Bimo. 1994. Psikologi Sosial. Yogyakarta: Andi Offset. 